Crataegus araioclada Sarg. Upland woods, Natchitoches, Natchitoches Parish.

Crataegus blanda Sarg. Near Minden, Webster Parish (B. F. Bush, No. 633).

$\times$ Gleditsia texana Sarg. Waste ground near the Red River, Shreveport. Caddo Parish.

Zanthoxylum clava-Herculis L. Small tree in sandy soil or on river banks. Marchouse, St. Landry Parish and West Feliciana Parish.

\title{
NOTES ON NORTH AMERICAN TREES, $\mathbf{X}^{1}$
}

\author{
C. S. SARgent
}

\section{NEW SPECIES AND VARIETIES OF CRATAEGUS}

Crataegus swanensis ( $\S$ Crus-galli), n. sp.

Leaves oblong-obovate, acute and short-pointed at apex, gradually narrowed and cuneate at the acute base and finely serrate above the middle with acute straight or slightly incurved teeth; fully grown when the flowers open and then glabrous above and slightly villose below along the midrib and primary veins, and at maturity thin, dull yellow-green on the upper surface, slightly paler on the lower surface, $3-5 \mathrm{~cm}$. long and $2-2.5 \mathrm{~cm}$. wide, with a slender midrib glabrous or slightly pubescent below and thin conspicuous veins impressed on the upper side of the leaf; petioles slender, slightly wing-margined at apex, densely villose early in the season, becoming pubescent, 5-10 $\mathrm{mm}$. in length; leaves on vigorous shoots broad-obovoid to oval, often slightly lobed, more coarsely serrate, $5-6 \mathrm{~cm}$. long and 3.5-4 cm. wide. Flowers opening early in June, 1.2-1.5 $\mathrm{cm}$. in diameter, on long slender villose pedicels, in many-flowered globose villose corymbs; calyx-tube narrow-obconic, thickly covered with matted pale hairs, the lobes separated by wide sinuses, gradually narrowed from the base, slender, long-acuminate, laciniately glandular-serrate below the middle, slightly villose on the outer surface, densely covered with pale hairs on the inner surface; stamens 15; anthers yellow; styles 2 or 3 . Fruit ripening the middle of October, on stout villose pedicels in pendent clusters, ellipsoidal or subglobose, scarlet, $1 \mathrm{~cm}$. long and 8-9 mm. in diameter, the calyx little enlarged with a wide deep cavity pointed in the bottom and with spreading and reflexed persistent lobes; flesh thin, dry and mealy; nutlets 2 or 3 , rounded at the ends, rounded or occasionally grooved on the back, $6-8 \mathrm{~mm}$. long and 5-6 mm. wide, the narrow brown hypostyle extending to the middle.

A tree raised at the Arnold Arboretum from seeds (Seed List No. 2265) collected in 1906 by B. F. Bush at Swan, Christian County, Missouri, with stout branchlets densely villose early in their first season, becoming

1 Forpart Ix see p. 1 
dark chestnut brown, lustrous and marked by pale lenticels in the autumn and dull gray-brown the following year, and armed with many stout straight or slightly curved chestnut brown spines $2-6 \mathrm{~cm}$. in length.

There is unfortunately no specimen in the Arboretum herbarium from the tree from which this plant in the Arboretum was raised, and there are no notes concerning it. I venture, nevertheless, to describe it as a new species as it distinctly differs from the six species of this group previously described with pubescent corymbs and yellow anthers to which it is most closely related. Of these the four Louisiana species have thick coriaceous or subcoriaceous oblong-obovate leaves rounded or very rarely acute at apex. From C. Mohrii Beadle from western Georgia, central Alabama and eastern Mississippi, with obovate to rhombic usually acute leaves it differs in its larger flowers and fruit, in its densely villose corymbs and young branches, and in its more pubescent leaves. From $C$. insignis Sargent from the neighborhood of Kahokia and East St. Louis, Illinois, it differs in the shape of its less coarsely serrate leaves, smaller flowers in much more villose corymbs and sinaller fruit.

\section{Crataegus ohioensis ( $\S$ Crus-galli) n. sp.}

Leaves oblong-obovate, acute and short-pointed or acuminate at apex, gradually narrowed and cuneate at base, finely and often doubly serrate usually only above the middle with straight teeth; more than half grown when the flowers open, and then glaucous below and glabrous, and at maturity thin, dark yellow-green, lustrous above, $5-8 \mathrm{~cm}$. long, $1.8-4 \mathrm{~cm}$. wide, with a thin midrib and slender prominent primary veins; petioles stout, grooved on the upper side, wing-margined nearly to the base, 6-10 $\mathrm{mm}$. in length; leaves on vigorous shoots oblong-obovate to elliptic, rounded or acute at apex, coarsely serrate. Flowers opening from the 20 th to the end of May, $1.3-1.5 \mathrm{~cm}$. in diameter, on slender pedicels, in wide many-flowered slightly villose corymbs, their bracts and bractlets slender, elongated, glandular; calyx-tube narrow-obconic, glabrous, the lobes slender, acuminate, entire, glandular-villose near the apex, glabrous; stamens 20, anthers pale pink; styles 2-5. Fruit ripening at the end of September or early in October, ellipsoidal to obovoid, reddish green, dotted, 1-1.5 cm. long, 7-8 mm. in diameter, and crowned with the enlarged erect persistent calyx-lobes, the cavity deep and narrow; flesh hard and dry; nutlets $2-5$, rounded at the ends, prominently ridged on the back, 5-7 mm. long, 4-5 mm. wide, the narrow dark hypostyle extending to just below the middle.

A tree sometimes $10 \mathrm{~m}$. high, with a stout trunk often divided into several stems, a broad round-topped head of spreading light green branches and slender glabrous branchlets gray-green when they first appear, becoming reddish brown in their second year and armed with occasional slender nearly straight chestnut-brown lustrous spines 3-4 $\mathrm{cm}$. in length, persistent and compound on old branches and trunks. 
Oнiо. Franklin County, roadsides near Columbus, $R$. E. Horsey and J. H. Schaffner, No. 2330 May 18, 1914; E. R. Horsey, No. 130, September 22, 1914; E. R. Horsey, No. 233 (type) May 14, 1915.

This tree differs from the described species of the Crus-galli Group with 20 stamens and rose colored or pink anthers in its narrow acute thin leaves, slightly villose corymbs and in the erect calyx lobes of the fruit.

Crataegus Warneri ( $§$ Crus-galli), n. sp.

Leaves ovate to oval or obovate, rounded or acute and short-pointed at apex, gradually or abruptly narrowed and cuneate at base, and coarsely serrate above the middle with straight gland-tipped teeth, nearly fully grown when the flowers open and then covered above with short white hairs and villose below along the midrib and primary veins, and at maturity thin, dark green and glabrous or occasionally still villose on the midrib above, pale and still villose below along the slender midrib and primary veins, 3.5-5 cm. long and $2.5-3.5 \mathrm{~cm}$. wide; petioles stout, wing-margined to the base, densely villose at maturity, $5-7 \mathrm{~mm}$. in length; leaves on vigorous shoots broad-ovate to semiorbicular, short-pointed at the rounded or acute apex, rounded and gradually narrowed below into a broad wing extending nearly to the base of the short petiole, more coarsely serrate, subcoriaceous, roughened above, $4.5-6 \mathrm{~cm}$. long and broad, with a stout midrib and primary veins villose below. Flowers opening from the 10th to the middle of April, 1-1.2 cm. in diameter, on stout densely villose pedicels in compact many-flowered villose corymbs; calyx-tube narrowobconic, thickly covered with matted pale hairs, the lobes narrowed from a broad base, slender, acuminate, glandular-serrate, slightly villose on the outer surface, puberulous on the inner surface; stamens 10; anthers redpurple; styles 2, rarely 3. Fruit ripening late in September, on slightly villose pedicels, ellipsoidal to subglobose, orange-red, 6-9 $\mathrm{mm}$. long, the calyx little enlarged with a short tube and a wide shallow cavity flat in the bottom and with spreading often deciduous lobes; nutlets 2 or 3 , rounded at the ends, ridged on the back with a broad deeply grooved ridge, $4 \mathrm{~mm}$. long and $3.5-4 \mathrm{~mm}$. wide, the narrow hypostyle extending to the middle.

A tree 7-8 m. high, with a slender stem covered with dark bark scaly near the base, erect branches forming a narrow head, and slender branchlets red-brown and covered with pale hairs when they first appear and dull gray and glabrous in their second year, and armed with occasional stout or slender chestnut-brown spines 3-4. $\mathrm{cm}$. long; or a shrub 3 or $4 \mathrm{~m}$. tall.

Texas. Wa lke r County, Huntsville, E. J. Palmer, No. 12037, May 24, 1917, April 18, 1918; R. S. Warner, April 12, 1918. Cherokee Coun ty, Larissa, E.J. Palmer, No. 13346, April 16, 1918, No. 14446, September 18, 1918. Anders on Cou nty, Palestine, E.J. Palmer, No. 13360 (type), No. 14445, September $17,1918$.

Extremely rare in the three stations where it has been found, this Thorn is arborescent only at Palestine where it grows in woods. In Walker 
and Cherokee Counties where it grows on dry banks it is a shrub, with several stems not more than $3 \mathrm{~m}$. high.

Until the stones of the fruit are examined this species might pass for one of the Macracanthae Group, although the entire absence of lobes from the leaves and the rather compact corymbs are unusual in plants of that Group. Although it is an extreme form it is now referred with some doubt to the Crus-galli Group. The species of that Group which it most resembles is C. sublobulata Sargent from San Augustine, Texas, which differs in its slightly lobed glabrous thicker leaves, its broader glabrous corymbs, and in its 20 stamens with pink anthers.

Crataegus poliophylla ( $§$ Virides), n. sp.

Leaves oblong-obovate to elliptic, acute or acuminate at apex, gradually narrowed and cuneate at base, finely doubly serrate above the middle with straight teeth and usually irregularly divided toward the apex into short acute lobes; thickly covered when they unfold with white hairs longer and more abundant on the lower than on the upper surface, nearly glabrous above when the flowers open and more or less pubescent below, and at maturity subcoriaceous, glabrous, yellow-green and lustrous on the upper surface, pale on the lower surface, $3-4 \mathrm{~cm}$. long and $2.5-3 \mathrm{~cm}$. wide, with a prominent midrib and slender veins deeply impressed above; on leading shoots up to $6 \mathrm{~cm}$. long and $4.5 \mathrm{~cm}$. wide; petioles slender, deeply grooved, narrowly wing-margined toward the apex, densely villose-pubescent early in the season, becoming glabrous, $1.5-2 \mathrm{~cm}$. in length. Flowers opening late in March or early in April, $1.5 \mathrm{~cm}$. in diameter, in wide lax 7-15-flowered densely villose corymbs; calyx-tube broad-obconic, villose like the slender pedicels, the lobes short, gradually narrowed from the base, glandular-serrate or nearly entire, glabrous on the outer surface, slightly villose on the inner surface; stamens 20; anthers yellow; styles 4 or 5. Fruit ripening late in September, in pendent clusters, globose to short-oblong or ovoid, orange-red, 6 or $7 \mathrm{~mm}$. in diameter, the calyx prominent, with a short tube, reflexed lobes and a wide shallow cavity broad in bottom; nutlets 4 or 5 , rounded at apex, gradually narrowed at base, slightly grooved on the back, 3-4 mm. long, 2.5-3 $\mathrm{mm}$. wide, the narrow hypostyle extending to the middle.

A tree occasionally 4 or $5 \mathrm{~m}$. high, with a trunk $8-10 \mathrm{~cm}$. in diameter, covered with dark rough bark, smooth ashy gray branches and slender branchlets thickly covered early in the season with long matted white hairs, becoming glabrous and ashy gray, and armed with slender straight spines $1.5-2.5 \mathrm{~cm}$. in length.

Texas. Brazoria County, B. F. Bush, No. 11 (5D), March 27, 1901, No. 870 (59), September 21, 1901, No. 970 (5b), October 2, 1901, No. 1212 '(type), March 26, 1902. Fort Bend County, thickets in drained soil, Duke, E. J. Palmer, No. 5083 (3a), April 2, 1914, No. 6695 (3a), October 1, 1914.

Distinct in the shape of the coriaceous leaves and in their villose covering while young, and in the villose corymbs. Two specimens collected at 
Columbia by B. F. Bush (No. 971), October 3, 1901, with thicker and more lustrous broad-ovate leaves up to $8 \mathrm{~cm}$. long and $7 \mathrm{~cm}$. wide, rather larger fruit and more zigzag branchlets probably represent an extreme form of this species. Much land has been cleared in the neighborhood of Columbia in recent years and this tree has probably disappeared as various attempts to rediscover it have failed.

Crataegus stenosepala ( $\S$ Virides), n. sp.

Leaves elliptic to oblong-elliptic or obovate, acute or acuminate at apex, gradually narrowed and cuneate at base, sharply and coarsely serrate above the middle with straight teeth, and often divided toward the apex into short lobes; when they unfold deeply tinged with red and slightly pubescent, nearly fully grown when the flowers open and then roughened above by short white hairs and conspicuous below by the thick snow-white pubescence along the midrib and on the petioles, the villose primary veins and by the axillary clusters of white hairs, and at maturity glabrous, yellow-green and lustrous on the upper surface, paler on the lower surface, $3.5-5.5 \mathrm{~cm}$. long and $1.5-3 \mathrm{~cm}$. wide, with a thin midrib and slender primary veins impressed above; petioles 6-7 mm. in length; leaves on vigorous shoots oblong-obovate, thicker, acuminate, cuneate at base, more coarsely serrate and more deeply lobed and up to $7 \mathrm{~cm}$. in length and $4 \mathrm{~cm}$. in width. Flowers opening toward the end of March, $2 \mathrm{~cm}$. in diameter, in wide loose 10-20-flowered slightly villose corymbs; calyxtube broad-obconic, sparingly covered with long white ridged hairs, the lobes gradually narrowed from the base, slender, long-acuminate, minutely and irregularly serrate, glandular-ciliate, glabrous on the outer surface, obscurely ciliate on the inner surface, 7-8 mm. long; stamens 20; anthers pale yellow; styles 5. Fruit ripening early in October, ellipsoidal to slightly obovoid, on slender glabrous pedicels in drooping clusters, orangered, 7 or $8 \mathrm{~mm}$. long, 5-6 mm. thick, with thin dry flesh, the calyx with a distinct tube, spreading lobes and a deep narrow cavity pointed in the bottom; nutlets 4 or 5 , rounded at base, acute at apex, only slightly grooved on the back, $7-8 \mathrm{~mm}$. long and $3-4 \mathrm{~mm}$. wide, the pale broad hypostyle extending to the middle.

A shrub or small tree 4-5 m. high, with stems forming large thickets, and covered with dark slightly scaly bark and slender slightly zigzag branchlets covered when they first appear with long matted white hairs, becoming glabrous and light red-brown during their first season and ashy gray in their second year, and armed with numerous nearly straight slender spines 2-4 cm. in length.

Texas. Fort Bend County, low well drained soil near Duke, $E . J$ Palmer, Nos. 5093 (10a) and 6701 (10a, type) April 2 and October 1, 1914.

Distinct from the species of this Group in the remarkably long slendre calyx-lobes and conspicuous when in flower from the broad band of snow white tomentum covering the under side of the lower half of the midrib of the leaves. 


\section{Crataegus abbreviata ( $\S$ Virides), n. sp.}

Leaves ovate to obovate, elliptic or suborbicular, acute or rounded and abruptly short-pointed at apex, narrowed and cuneate or rounded at base, sharply often doubly glandular-serrate usually only above the middle, and often slightly divided usually toward the apex into short acute lobes; covered above when they unfold with short white hairs and densely tomentose below, fully grown when the flowers open and then glabrous with the exception of a few hairs along the upper side of the midrib, and of small axillary tufts below, and at maturity thin, yellow-green, glabrous, and 2.5-3 cm. long and 2-2.5 $\mathrm{cm}$. wide, often appearing 3-nerved by the greater prominence of the lowest pair of primary veins; petioles slender, slightly villose-pubescent early in the season, soon becoming glabrous; leaves on vigorous shoots broad-ovate to semiorbicular or elliptic, rounded or acuminate at apex, rounded or cuneate at base, often laterally lobed, 4-5 cm. long and broad. Flowers opening early in April, 1.8-2 cm. in diameter, in slightly villose compact usually 10-15-flowered corymbs crowded on the branches; calyx-tube broad-obconic, slightly villose, the lobes short, entire, often slightly villose or glabrous on the outer surface, villose on the inner surface, mostly deciduous from the ripe fruit; stamens 20; anthers yellow; styles 4 or 5 . Fruit ripening early in October, on slightly villose pedicels, in lax drooping clusters, subglobose, dark red, 6-8 mm. in diameter, with thin succulent flesh, the calyx little enlarged, with a deep cavity broad in the bottom; nutlets 4 or 5 , rounded at the ends, broader at the apex than at the base, slightly grooved on the back, 3-4 $\mathrm{mm}$. long, the narrow hypostyle extending to the middle.

A tree 5-5.5 m. high, with a small stem and slender nearly straight branchlets slightly villose when they first appear, dark orange-brown and glabrous or nearly glabrous when the flowers open, and gray-brown in their second year, and unarmed or furnished with occasional slender straight spines $3-4 \mathrm{~cm}$. in length.

Texas. B ra z o s County, low woods on the Brazos River, near Brazoria, E. J. Palmer, Nos. 5131 (4) and 6734 (4, type), April 7, and October 5, 1914.

Although there is little in the flowers and fruit or in the habit of this plant to distinguish it from some of the other Virides species which grow in the valley of the lower Brazos River, where this Group is represented perhaps by its greatest diversity of forms, the short small leaves are so distinct in shape that until the Texas species are better known it appears necessary to treat it as a species.

\section{Crataegus desertorum (§ Virides), n. sp.}

Leaves ovate to slightly obovate or suborbicular, acute, acuminate or rounded at apex, gradually or abruptly narrowed and cuneate at base, finely doubly serrate usually only above the middle with blunt glandular teeth, and often slightly divided into short acute lobes; covered when they unfold with short lustrous white hairs, and villose below along the midrib 
and primary veins, and at maturity thin, yellow-green and slightly roughened above by short white hairs, pale and glabrous or occasionally slightly villose toward the base of the prominent midrib below, $1.5-2 \mathrm{~cm}$. long and 1-1.5 $\mathrm{cm}$. wide, with three or four pairs of primary veins extending to the points of the lobes, or 3-nerved from the base; petioles slender, wing-margined to the middle, densely villose early in the season, becoming nearly glabrous in the autumn, 5-6 mm. in length; leaves on vigorous shoots ovate, broad and rounded at base, acute at apex, often deeply lobed, 2-2.5 $\mathrm{cm}$. long and wide. Flowers appearing after the middle of April, small, in 4- or 5-flowered lax glabrous corymbs; calyx broadobconic, slightly villose, the lobes slender, acuminate, obscurely serrate, glabrous on the outer surface, villose on the inner surface; stamens 20; anthers pale yellow; styles 4 or 5 . Fruit ripening the middle of October, subglobose, orange-red, 4-5 $\mathrm{mm}$. in diameter, with thin dry flesh; the calyx enlarged and prominent, with erect or spreading glabrous lobes and a wide shallow cavity broad in the bottom; nutlets 4 or 5 , rounded and rather broader at apex than at base, only slightly grooved on the back, $4 \mathrm{~mm}$. long and $2.5-3 \mathrm{~mm}$. wide, the broad pale hypostyle extending to below the middle.

A shrub $3 \mathrm{~m}$. high, with stems covered with thin pale bark flaky near their base, and slender unusually zigzag branchlets red-brown and slightly villose when they first appear, soon glabrous, ashy gray at the end of their first season and horribly armed with many slender straight or slightly curved chestnut-brown ultimately gray spines $2.5-5 \mathrm{~cm}$. in length.

Texas. Uvalde County, in the rocky bed of a creek usually dry, but flooded during a few hours two or three times during the year, near Uvalde, E. J. Palmer, Nos. 11348, 12379 (type), 12973, March 22, June 17, October 12, 1917; Nos. 13322, 13498, 13699, 14496, April 6, May 5, May 26, September 24, 1918.

In its unusually zigzag branches, numerous long slender spines and minute fruit this is perhaps the most distinct species of the Virides Group. The fact that it inhabits a region of rare rainfall where the soil in which it grows is only thoroughly wet two or three times in the year would be remarkable for any species of Crataegus; it is the more remarkable for a species of this Group, for the Virides, growing usually in low ground, are moisture loving plants. It is unfortunate that Mr. Palmer has been able to find only a single plant.

\section{Crataegus tripartita ( $($ Virides), n. sp.}

Leaves usually elliptic, acute or acuminate at apex and gradually narrowed to the cuneate base, or rarely ovate or obovate and broadcuneate or rounded at base, finely serrate above the middle with straight or slightly incurved teeth, rarely slightly lobed, often furnished below early in the season with axillary tufts of snow-white pubescence, otherwise glabrous, subcoriaceous, yellow-green, lustrous above, $3-4 \mathrm{~cm}$. long, $1.5-2.5 \mathrm{~cm}$. wide, with a thin midrib and slender prominent veins deeply impressed on the upper surface; petioles slender, narrowly wing-margined 
often to below the middle, 1-2 cm. in length; leaves on vigorous shoots broad-ovate, rounded, truncate, or abruptly cuneate at the wide base, often 3-lobed by narrow sinuses extending nearly to the midrib, the terminal lobe often lobulate, coarsely glandular-serrate, conspicuously reticulate-venulose with a vein often extending to the bottom of a sinus, 3-4 cm. long and $2-3 \mathrm{~cm}$. wide, their petioles stout, wing-margined, glandular, 1-1.5 cm. in length. Flowers opening late in March, 1.5-2 cm. in diameter, on slender glabrous pedicels, in small 7-10-flowered corymbs closely set on the branches; calyx-tube abruptly enlarged upward, glabrous, the lobes gradually narrowed from a broad base, acuminate, entire, glabrous, usually deciduous from the fruit; stamens 20; anthers pale yellow; styles 5. Fruit ripening after the middle of September, short-oblong, yellow-green, $7-10 \mathrm{~mm}$. long and 5-8 mm. wide, with soft succulent flesh, the calyx little enlarged, with a deep narrow cavity; nutlets 5 , acute at ends, only slightly grooved on the back, 3-4 mm. long, the narrow hypostyle extending to the middle.

A shrub with several stems, 3-3.5 m. tall, or a round-topped tree 6 or $7 \mathrm{~m}$. high, with dark gray scaly bark, and slender straight or slightly zigzag glabrous branchlets dark reddish brown when they first appear, becoming lighter-colored at the end of their first season, and ashy gray the following year, and armed with occasional slender nearly straight chestnut brown spines $2-3 \mathrm{~cm}$. in length.

Texas. Brazoria County, low woods along the Brazos River, near Columbia, B. F. Bush, No. 948, September 30, 1901, No. 2, March 24, 1909 E. J. Palmer, No. 5040 (5), March 27, 1914, September 28, 1914 (type), No. 5102 (8), April 4, 1914, No. 6688 (8), September 30, 1914.

Distinct in the subcoriaceous leaves, those on vigorous branchlets often deeply 3-lobed with lobes coarsely glandular serrate to the base, and in its yellow-green fruit.

Crataegus anamesa ( $\$$ Virides), n. sp.

Leaves elliptic to broad-ovate or slightly obovate, acute at apex, gradually or abruptly narrowed and cuneate at base, finely serrate with short broad teeth, and of ten slightly divided above the middle into broad rounded lobes; when they unfold tinged with red, and villose above and thickly covered below with matted white hairs, not more than half grown when the flowers open and then glabrous or nearly glabrous above, sparingly villose and conspicuous below by the broad band of snow-white hairs along the lower part of the midrib, and at maturity subcoriaceous, nearly glabrous, dark green and lustrous on the upper surface, pale on the lower surface, $3-5 \mathrm{~cm}$. long and 3-5 cm. wide; petioles slender, densely villose early in the season, becoming glabrous, $1.5-2 \mathrm{~cm}$. in length; leaves on vigorous shoots broad-ovate, rounded or acute at apex, rounded or broad-cuneate at base, finely serrate, slightly lobed with short broad lobes, up to 6 or $7 \mathrm{~cm}$. long and wide, their petioles stout, slightly wingmargined at apex, often furnished with occasional glands, $2.5-3 \mathrm{~cm}$. in 
length. Flowers appearing at the end of March or early in April, 2-2.5 cm. in diameter, in compact mostly 10-15-flowered densely villose corymbs crowded on the branches; calyx-tube narrow-obconic, glabrous except for occasional short white hairs, the lobes gradually narrowed from the base, entire or rarely minutely dentate, glabrous on the outer surface, villose on the inner surface, mostly deciduous from the ripe fruit; stamens 20; anthers pale yellow; styles 4 or 5 . Fruit ripening early in October, on nearly glabrous pedicels, in few-fruited drooping clusters, subglobose to short-oblong or slightly obovoid, dark red, 9-10 mm. in diameter, the calyx little enlarged, with a narrow deep cavity pointed in the bottom; nutlets 4 or 5 , narrowed and rounded at the ends, only slightly grooved on the back, about $5 \mathrm{~mm}$. long, the dark narrow hypostyle extending to below the middle.

A shrub 4-5 m. high, with stems covered with gray slightly scaly bark, small erect smooth dark gray branches and slender slightly zigzag branchlets densely covered with white hairs early in the season, becoming glabrous and dull reddish brown by autumn, and dark gray the following year and apparently without spines.

Texas. Fort Bend County, Duke, E. J. Palmer, Nos. 5090 (8) and 6698 (8), April 2 and October 1914 (type).

The size of the fruit of this species is intermediate between that of typical $C$. viridis Linnaeus and that of a small group of species with fruit from $1.5-2 \mathrm{~cm}$. in diameter of which $C$. nitida Sargent is the best known. Although much more pubescent, this Texas shrub resembles in the shape of its leaves another of the large-fruited Virides species, C. atrorubens Ashe of East St. Louis, Illinois.

Crataegus antiplasta ( $($ Virides), n. sp.

Leaves ovate to elliptic or semiorbicular, acute or rounded at apex, cuneate at base, finely doubly serrate above the middle with straight teeth, dark red and covered with short white hairs when they unfold, almost fully grown when the flowers open and then nearly glabrous above and slightly villose along the midrib and primary veins below, and at maturity thin, dark green and glabrous on the upper surface, paler and glabrous or still villose on the midrib and veins below, 3-4 cm. long and 2-3 cm. wide, with veins slightly impressed above; petioles slender, slightly wing-margined at apex, villose early in the season, becoming glabrous, $1-1.5 \mathrm{~cm}$. in length; leaves on vigorous shoots ovate to suborbicular, acute at apex, rounded or cuneate at base, more coarsely serrate, sometimes slightly 3 -lobed by narrow sinuses, up to 5 or $6 \mathrm{~cm}$. long and $3-4 \mathrm{~cm}$. wide, their petioles stout, broadly wing-margined nearly to the middle, occasionally glandular, often sparingly villose through the season, 8-10 $\mathrm{mm}$. in length. Flowers opening late in March or early in April, $2.5 \mathrm{~cm}$. in diameter, in compact glabrous mostly 5-10-flowered corymbs; calyx-tube narrow-obconic, glabrous, the lobes gradually narrowed from a broad 
base, slightly dentate, glabrous on the outer surface, villose on the inner surface, usually deciduous from the ripe fruit; stamens 20; anthers pale yellow; styles 4 or 5. Fruit ripening early in October, subglobose, scarlet, 7-8 mm. in diameter, with thin dry flesh, the calyx little enlarged, with a wide deep cavity broad in the bottom; nutlets 4 or 5 , rounded at the ends, rather broader at apex than at base, only slightly grooved on the back, the wide hypostyle extending to the middle.

A tree 4-5 m. high, with a slender stem covered with close gray bark, separating into small scales, erect dark gray branches and slender straight or slightly zigzag branchlets thickly covered when they first appear with matted white hairs, becoming glabrous and reddish brown in their first season and ashy gray the following year, and armed with numerous nearly straight or slightly curved ashy gray spines. 2-3.5 cm. in length.

Texas. Fort Bend County, rich prairies near Duke, E.J.Palmer, Nos. 5082 (3) (type). and 6894 (3).

From related species this little tree can be distinguished by the often nearly orbicular or occasionally slightly 3-lobed leaves on vigorous branchlets and by the small loosely attached scales of the bark of the trunk.

Crataegus antimima ( $§$ Virides), n. sp.

Leaves ovate, elliptic or rarely obovate, acute or acuminate at apex, abruptly or acutely cuneate at base, finely doubly serrate above the middle with straight teeth and slightly lobed with acute lateral lobes; covered above when they unfold with short caducous white hairs and usually furnished below with axillary tufts of white pubescence, and at maturity thin, yellow-green and lustrous on the upper surface, dull and paler on lower surface, 3-4 $\mathrm{cm}$. long and $2.5-3 \mathrm{~cm}$. wide, with a thin midrib and primary veins impressed above; petioles slender, slightly wing-margined at apex, thickly coated until after the flowers open with matted white hairs, becoming glabrous, 5-12 $\mathrm{mm}$. in length; leaves on vigorous shoots oblong to ovate or obovate, more coarsely serrate and usually more deeply lobed, up to 6-7 cm. long and 4-4.5 cm. wide. Flowers opening late in March or early in April, $2 \mathrm{~cm}$. in diameter, in small compact usually 7-12-flowered glabrous corymbs; calyx-tube broad-obconic, glabrous, the lobes abruptly narrowed from a broad base, slender, acuminate, entire, glabrous, often deciduous from the ripe fruit; stamens 20; anthers pink, styles 5, surrounded at base by a conspicuous ring of white tomentum. Fruit ripening early in October, on slender pedicels in drooping clusters, subglobose to slightly obovoid, dark orange-red, 7-8 mm. in diameter; with thin soft flesh, the calyx little enlarged, with a narrow cavity not contracted in the bottom; nutlets 5 , rounded at the ends, broader at apex than at base, only slightly grooved on the back, 4-5 mm. long, 2.5-3 mm. wide, the narrow hypostyle extending to the middle.

A shrub 4-5 m. high, with stems covered with dark slightly scaly bark, small erect dark gray branches, and slender nearly straight branchlets 
thinly covered when they first appear with matted pale hairs, soon glabrous, reddish brown during their first season, becoming ashy gray and unarmed or occasionally furnished with short slender straight spines sometimes becoming compound on main stems.

Texas. Fort B en d Cou n ty, near Duke, E. J. Palmer Nos. 5092 (10) and 6700 (10), April 2 and October 1, 1914 (type).

This species, which resembles C. poliophylla Sargent of the same general region in the shape of the leaves and in the size of the flowers, differs from it in the nearly entire absence of pubescence which is so conspicuous on C. poliophylla, and in the pink not yellow anthers

\section{Crataegus sutherlandensis ( $§$ Virides), n. sp.}

Leaves ovate, acute at apex, gradually or abruptly narrowed and concave-cuneate at base, coarsely doubly serrate with straight or incurved acuminate teeth; coated with pale pubescence when they unfold, soon glabrous, fully grown when the flowers open, and at maturity thin, dull yellow-green, slightly scabrate on the upper surface, $3-4 \mathrm{~cm}$. long and 2-2.5 cm. wide, with a thin midrib and slender primary veins slightly raised on the upper surface; petioles slender, slightly wing-margined, sparingly villose early in the season, soon glabrous, 8-15 $\mathrm{mm}$. in length; leaves on vigorous shoots rounded at base, often irregularly divided into short wide lateral lobes, $4-5 \mathrm{~cm}$. long and broad. Flowers opening late in March, $2 \mathrm{~cm}$. in diameter, on long slender glabrous pedicels, in lax usually 7-10-flowered corymbs; calyx-tube narrow-obconic, glabrous, the lobes slender, acuminate, often laciniately divided near the base into glandular teeth, glabrous on the outer surface, villose-pubescent on the inner surface; stamens 20; anthers faintly tinged with pink; styles 5 . Fruit ripening the end of September, subglobose, often truncate at base, orange-red, 7-8 mm. in diameter, the calyx prominent, with erect and spreading lobes and a narrow deep cavity; nutlets 5 , rounded at apex, acute at base, obscurely grooved on the back, 5-6 $\mathrm{mm}$. long, 3-4 $\mathrm{mm}$. wide, the broad conspicuous hypostyle extending nearly to the base.

A slender tree 4 or $5 \mathrm{~m}$. high, with a trunk covered with dark gray bark separating freely into long thin oblong flakes disclosing the red inner bark, erect and spreading branches, their bark smooth and gray, and slender slightly zigzag branchlets orange-green and sparingly pilose above when they first appear, soon red-brown and glabrous, and ashy gray in their second season, often unarmed or furnished with occasional straight slender spines up to $5 \mathrm{~cm}$. in length.

Texas. Wilson County, rich upland woods on the Cibalo River, near Sutherland Springs, B. Mackensen, No. 3, March 27, 1910, No. 257, September 28, 1913; C. S. Sargent, Nos. 6 and 7, March 30, 1913; E. J. Palmer, No. 9206 (No. 3), March 17 and 30, 1916, No. 9300 (No. 3), March 30, 1916, No. 10805 (No. 3), September 23, 1916, No. 9291 (No. 3a), March 30, 1916, No. 9292 (4), March 30, 1916, No. 10799 (4), September 25, 1916 (type), No. 9293 (4a), March 30,1916 , No. 10800 (4a), September 25, 1916, No. 9295 (4b), March 30, 1916 
No. 10802 (4b), September 25, 1916, No. 10798 (3a), September 25, 1911, No. 9307 (6), March 30, 1916, No. 10812 September, 25, 1916.

Crataegus sutherlandensis var. spinescens Sarg., n. var.

Differing from the type in its rather smaller leaves more pubescent early in the season and often furnished below with conspicuous tufts of white axillary hairs, and in its larger and more numerous spines.

A shrub or small tree 4-5 m. high, forming thickets of slender stems covered with dark scaly bark separating in small narrow scales, slender zigzag branchlets armed with many slender straight spines from $3-6 \mathrm{~cm}$. in length.

Texas. Wil s o n C o u n t y, low woods near Sutherland Springs, C. S. Sargent April 8, 1915; E. J. Palmer, Nos. 9294 and 10801 (5), March 30 and September 25, 1916 (type), No. 9308 and 10816 (5a) March 30 and September 25, 1916.

Crataegus caerulescens ( $§$ Pruinosae), n. sp.

Leaves glabrous, acuminate at apex, broad-cuneate to rounded at base, deeply laterally lobed with acuminate lobes, and finely doubly serrate with straight or slightly incurved gland-tipped teeth; thin and fully grown the end of May, and at maturity thick, dark blue-green and dull on the upper surface, pale blue-green on the lower surface, $4-4.5 \mathrm{~cm}$. long and 3-3.5 $\mathrm{cm}$. wide, with a thin prominent midrib and slender primary veins extending to the points of the lobes; petioles slender, furnished with occasional glands, $1-1.5 \mathrm{~cm}$. in length; leaves on vigorous shoots often truncate at base and $4 \mathrm{~cm}$. long and broad. Flowers opening the end of May, 1.8-2 $\mathrm{cm}$. in diameter, on long slender pedicels in small compact corymbs with narrow glandular-serrate bracts and bractlets; calyx-tube broad-obconic, the lobes short, narrowed from a wide base, acuminate, glabrous; stamens 18-20; anthers white; styles 4 or 5 . Fruit erect on slender pedicels, ripening in October, obovoid, gradually narrowed from near the top to the acute base, dull red covered with a glaucous bloom, $1 \mathrm{~cm}$. long and 7-8 mm. in diameter, the calyx little enlarged with a short tube, a wide shallow cavity broad in the bottom, and spreading and reflexed persistent lobes; nutlets 4 or 5 , rounded at apex, gradually narrowed and acute at base, 8-9 $\mathrm{mm}$. long and $3 \mathrm{~mm}$. wide.

A plant with a single stem, now almost $3 \mathrm{~m}$. high with slender nearly straight glabrous branchlets yellow-green when they first appear, becoming light red-brown at the end of their first season and dull gray-brown the following year, and armed with numerous slender straight or slightly curved chestnut brown spines 3-4.5 cm. in length.

Arnold Arboretum No. 4572 (type), September 27, 1912, May 27, 1919. A plant brought to the Arboretum by C. E. Faxon from Orient Heights, Breeds Islands, Boston Harbor in the autumn of 1899.

This plant is peculiar in the blue color of the leaves. It is most closely related to $C$. Porteri Britton from Tannersville and Stroudsburg, Pennsylvania, a species also with blue leaves, 20 stamens and white anthers, but 
the leaves of that species are all acutely cuneate at base, thicker and lustrous on the upper surface, the flowers are larger in usually fewerflowered corymbs, and the fruit is less gradually narrowed to the base with a narrow cavity pointed in the bottom, and droops on more slender pedicels. C. Porteri as it grew in 1908 in the woods in low undrained soil in the neighborhood of Tannerville was a slender shrub about $5 \mathrm{~m}$. high.

\section{Crataegus ellipticifolia ( $§$ Pruinosae), n. sp.}

Leaves elliptic, acute at the ends, divided above the middle into short acute lobes, and finely often deeply serrate often to below the middle with acute glandular teeth; covered above when they unfold with short white hairs, becoming glabrous, and at maturity thin, smooth and yellow-green on the upper surface, paler below, 4-5 cm. long and $2.5-3.5 \mathrm{~cm}$. wide, with a slender midrib and primary veins; petioles slender, glabrous, $2-3 \mathrm{~cm}$. in length; leaves on vigorous shoots often broad-ovate, rounded or truncate at base, occasionally deeply lobed, more coarsely serrate, 4-6 cm. long and 4-5 cm. wide. Flowers opening late in May, 1-1.2 cm. in diameter, on long slender pedicels, in mostly $7-9$-flowered slightly villose corymbs with long slender conspicuous bracts and bractlets; calyx-tube narrowobconic, glabrous, the lobes gradually narrowed from a broad base, slender, acuminate, entire or rarely furnished with an occasional tooth, glabrous; stamens 20; anthers small, creamy white; styles 5. Fruit ripening early in October, short-oblong to subglobose, only slightly angled, hard, turning dull red at maturity, about $1 \mathrm{~cm}$. in diameter, the calyx only slightly enlarged with a short tube, spreading closely appressed lobes, and a deep narrow cavity rounded in the bottom; nutlets broad and rounded at base, narrower and often acute at apex, prominently ridged on the back with a deeply grooved ridge, $5-6 \mathrm{~mm}$. long and $3.5-4.5 \mathrm{~mm}$. wide, the narrowpale hypostyle extending to below the middle.

A shrub forming thickets with slender slightly zigzag glabrous branchlets, yellowish green early in their first season, becoming light red-brown, and armed with slender nearly straight chestnut-brown spines persistent and often compound on old stems.

OHio. Delaware County, in pastures, near Delaware, E. R. Horsey, No. 123, September 25, 1913, No. 231 (type), May 27 and September 25, 1914.

From other Pruinosae with leaves covered above while young with short white hairs, flowers with 20 stamens and white or yellow anthers this species differs in its elliptic leaves.

Crataegus mariettensis ( $($ Pruinosae), n. sp.

Leaves oblong-ovate, acuminate, rounded or truncate at base, slightly divided into three or four pairs of short broad acute lobes, and coarsely doubly serrate with straight glandular teeth; tinged with red and covered above by white hairs when they unfold, nearly glabrous when the flowers open, and at maturity thin, yellow-green, smooth and glabrous above, 
paler below, 6-7 $\mathrm{cm}$. long and 4-5 $\mathrm{cm}$. wide, with a slender midrib and primary veins; petioles slender, glabrous, occasionally glandular, 2.5-3 $\mathrm{cm}$. in length; leaves on vigorous shoots, broad-ovate, rounded, truncate or cordate at base, more deeply lobed and more coarsely serrate, $5-6 \mathrm{~cm}$. long and broad, with petioles only $1.5-2 \mathrm{~cm}$. long. Flowers opening about May 20, 1.5-1.7 cm. in diameter, on slender pedicels, in small compact mostly 4-7-flowered glabrous corymbs with coarsely glandular-serrate bracts and bractlets; calyx-tube broad-obconic, glabrous, the lobes separated by wide sinuses, short, broad, acuminate, tipped with a dark gland, entire or obscurely glandular-serrate, glabrous; stamens 10; anthers pink, styles usually 5. Fruit ripening early in October, subglobose but broader than high, flattened at the ends, hard, green, 1-1.2 cm. in diameter, the calyx sessile with a shallow cavity 5 or $6 \mathrm{~mm}$. in diameter, the lobes deciduous; flesh thin, hard and dry, nutlets 5, rounded at the ends, slightly grooved on the back, 4 or $5 \mathrm{~mm}$. long and wide, the pale hypostyle nearly covering their inner faces.

A tree 6 or $7 \mathrm{~m}$. high, with a single small trunk covered with dark gray bark, separating near the base in loose scales, ascending branches forming an open head, and stout slightly zigzag glabrous branchlets light yellow-green when they first appear, becoming dark chestnut-brown, marked by pale lenticels and armed with numerous stout nearly straight dark chestnut brown spines persistent and becoming compound on the trunk and large branches.

OHio. W a s h ing t o n C o u n ty, near Marietta, R. E. Horsey, No. 602 (type), May 20 and September 30, 1917.

From the other species of this group already described with depressed globose fruit and a red shallow fruit calyx, this new species differs in the shape of the leaves which are not cuneate at base as in those species, but broad and rounded or truncate.

\section{Crataegus uvaldensis ( $§$ Molles), n. sp.}

Leaves ovate, acute and short-pointed at apex, concave-cuneate at base, slightly or on leading shoots more deeply lobed usually only above the middle with short acuminate lobes, and deeply doubly serrate often nearly to the base with slender acuminate gland-tipped teeth, covered above when they unfold with short ridged pale hairs and pale and villose below especially along the midrib and primary veins, and at maturity thin, dark dull green and scabrate on the upper surface, pale and nearly glabrous on the lower surface, $4-5 \mathrm{~cm}$. long and 3-3.5 cm. wide, with a slender slightly villose pale yellow midrib and primary veins; petioles slender, slightly wing-margined at the apex by the decurrent base of the blade, thickly covered early in the season with matted pale hairs, becoming pubescent, 6-15 mm. in length; leaves on vigorous shoots more deeply sometimes 3-lobed with large foliaceous coarsely and sharply serrate stipules. Flowers opening early in April, about $1 \mathrm{~cm}$. in diameter, on 
slender villose pedicels in small compact mostly 5-7-flowered corymbs, densely villose like the narrow obconic calyx-tube; calyx-lobes slender, acuminate, entire or minutely and irregularly glandular-serrate, pubescent on the outer surface, densely villose on the inner surface, deciduous from the ripe fruit; stamens 5-10; anthers yellow; styles 3-5. Fruit ripening early in October, on more or less densely villose erect pedicels in small clusters, globose, bright red, 1-1.4 cm. in diameter, slightly pubescent with a ring of white hairs surrounding the little enlarged calyx composed of a short tube and a deep narrow cavity pointed in the bottom, flesh thick and dry; nutlets 3-5, gradually narrowed and rounded at the ends, slightly ridged on the back, 4-5 $\mathrm{mm}$. long and 3-4 $\mathrm{mm}$. wide, the broad conspicuous hypostyle extending to below the middle.

A shrub 3-4 $\mathrm{m}$. high, with a stem covered with thin scaly bark, and slender nearly straight branchlets thickly covered when they first appear with matted pale hairs, light orange-brown and slightly hairy at the end of their first season and ashy gray and glabrous the following year, and armed with numerous slender straight gray spines $3-5 \mathrm{~cm}$. long.

Texas. U val d e C o un ty, foot of the bluff of the Sabinal River, Utopia, E. J. Palmer, No. 11525, April 10, 1917, No. 12946 (type), October 7, 1917. M en a r d County, low woods on the San Saba River, Menard, E. J. Palmer, No. 11889 (sterile branches only), May 12, 1917.

Distinct from the northern species of the Mollis Group in its small leaves, flowers and fruit and shrubby habit, this Texas shrub changes earlier conceptions of this Group.

Another species of the Mollis Group from western Texas with generally smaller less sharply serrate more pubescent leaves, flowers with 5-10 stamens, and rose-purple or pink anthers, and smaller fruit covered early in the season with short pale hairs but without the ring of white hairs at the base of the calyx with a wide shallow cavity and persistent lobes, is until that species is better known referred to C. Greggii Eggleston from the neighborhood of Saltillo, Cohuila, Mexico. As this species grows in Texas it is a tree 12 feet high which has been found on the bluffs of the Guadalupe River below Kerrville, Kerr County, B. Mackensen, No. 7, May 1, 1910, No. 1, April 13 and September 21, 1913, No. 2. April 13, 1913, No. 253, September 21, 1913, No. 4, September 21, 1913, No. 20 (same tree as No. 4), April 21, 1914; E. J. Palmer, No. 9922 (1), May 29, 1916, No. 10882, October 2, 1916, No. 11497, April 8, 1917.

A specimen with immature fruit collected by E.J. Palmer (No. 10168) on the bank of the Frio River near Leaky, Real County, June 11, 1916, and a specimen collected by him (No. 10899) at Junction, Kemble County, October 6, 1916, are also doubtfully referred to C. Greggii.

Crataegus rotundifolia var. aboriginum ( $\$$ Rotundifoliae), n. var.Crataegus aboriginum Sargent in Rhodora, v. 164 (1903).

Differing from $C$. rotundifolia Moench in its large obovate or ovate eaves acute or rounded at apex, up to $7-10 \mathrm{~cm}$. long and 5-8 cm. wide, 
in its flowers $2 \mathrm{~cm}$. in diameter, in its slightly villose corymbs, and in its larger fruit up to $1.5 \mathrm{~cm}$. in diameter, with a more prominent calyx with often erect lobes.

The description of $C$. aboriginum was based on a single individual found by Mr. J. G. Jack at Caughnawaga in the Province of Quebec in 1899 and 1890; it has since been collected at other stations, and a further acquaintance with this plant shows by intermediate forms that it cannot be distinguished specifically from $C$. rotundifolia. The larger leaves, flowers and fruit, and the slightly villose pedicels of the most of plants examined make it, however, desirable to distinguish it as a variety.

The original plant of C.aboriginum was a shrub with stems only $3 \mathrm{~m}$. high; the plants of St. Annes de Bellevue are trees from 7-8 m.tall. The following additional specimens are referred to this variety.

Canada. Provin ce of Quebe c, Caughnawaga, J. G. Jack, No, 97, September 24, 1900, St. Annes de Bellevue, near Macdonald College, J. G. Jack, Nos. 207 and 208, September 23, 1913, May 30, 1914; La Tortue, Brother M. Victorin, October 1920; Hill County, J. Dunbar, Nos. 172 and 187, September 18,1915 . Provin ce of On ta r i o, Gananoque, $J$. Dunbar, No. 18, June 11 and September 27, 1907, No. 66, September 1911, Belleville, J. Dunbar, No. 62, June 3, 1908, and September 26, 1907, Kingston, J. Dunbar, No. 128, October 14, 1912, June 1, 1913.

\section{Crataegus rotundifolia f. rubescens, $n$. forma.}

Differing from the type only in the distinctly red color of the leaves in spring and summer.

Canada. Provin ce of Qu e be c, St. Anne, Montreal Island, J. G. Jack, No. 202 (type), May 29 and September 23, 1913, Baie d'Urfe Station, G. T.R.R.. J. G. Jack, No. 206, September 23, 1913, No. 215, May 30 and September 25, 1914,

Plants raised at the Arboretum from the seed of No. 215 have retained the red color of their leaves.

\section{Crataegus mercerensis ( $§$ Rotundifoliae), n. sp.}

Leaves obovate to rarely ovate or semiorbicular, acute and shortpointed at apex, concave-cuneate at the entire base, usually slightly divided above the middle into short acute lobes, finely often doubly serrate with straight gland-tipped teeth, thin, glabrous, smooth and dark yellow-green on the upper surface, pale on the lower surface, 4-6 cm. long and 3-4 $\mathrm{cm}$. wide, with a thin midrib and slender veins running to the points of the lobes; petioles slender, narrowly wing-margined at apex, often furnished with occasional glands, sparingly villose on the upper side early in the season, soon glabrous, 1-2 cm. in length. Flowers appearing from the middle to the end of May, about $1 \mathrm{~cm}$. in diameter, on slender glabrous pedicels in 5-12-flowered glabrous compact corymbs with lanceolate to linear glandular caducous bracts and bractlets; calyx-tube narrowobconic, glabrous, the lobes abruptly narrowed from a wide base, short, serrate toward the acute or rarely 3-lobed apex, glabrous on the outer surface, slightly villose on the inner surface; stamens 10; anthers white; styles usually 3. Fruit ripening the end of September, on erect pedicels 
in few-fruited clusters, subglobose to short-oblong, orange-red, 1-1.2 $\mathrm{cm}$. in diameter, the calyx little enlarged with a wide deep cavity pointed in the bottom and spreading and appressed lobes; flesh thick, dry and mealy; nutlets usually 3 , rounded at the ends, broader at the apex than at the base, rounded and ridged on the back, about $5 \mathrm{~mm}$. long and 3 $\mathrm{mm}$. wide, the narrow hypostyle extending nearly to the middle.

A shrub with stems 3-4 mm. high, and slender nearly straight glabrous unarmed branchlets bright yellow-green early in their first season, becoming light red-brown and grayish brown in their second year.

West Virginia. Me r c e r C o u n ty, roadside between Princeton and Mercer Springs, T. G. Harbison, No. 22 (type), May 25 and 26, 1914; No. 40, September 28, 1914 .

This species in general appearance looks very distinct from the typical species of this group, but its relationship is suggested by $C$. dacrioides Sargent from Obisonia, Huntington County, southern Pennsylvania, another extreme form of Rotundifoliae from which it differs in its broader obovate to ovate nearly rhombic leaves destitute of hairs on the upper surface while young and smooth at maturity, smaller flowers on glabrous pedicels, by the subglobose or short-oblong not obovoid fruit and by the absence of thorns. The absence of thorns from the specimens collected by Mr. Harbison is, however, probably not a constant character.

Crataegus meiophylla ( $\$$ Rotundifoliae), n. sp.

Leaves ovate to slightly obovate, rounded or acute at apex, cuneate at base, divided above the middle into three or four pairs of short broad rounded or acute bluntly toothed lobes, roughened above when they unfold by short white hairs, and glabrous or furnished below along the midrib and veins with occasional hairs; nearly fully grown when the flowers open, and at maturity thin, glabrous, dark yellow-green above, paler below, 2-2.5 $\mathrm{cm}$. long and 1,5-2 cm. wide, with a thin prominent midrib and slender veins running to the points of the lobes; petioles slender, narrow, wing-margined to below the middle, $5-10 \mathrm{~mm}$. in length; leaves at the end of vigorous shoots sometimes broad-elliptic, acute at ends, divided into acute lobes, and 4-5 cm. long and wide; petioles up to 1.5 $\mathrm{cm}$. in length. Flowers appearing about May $20,1.5 \mathrm{~cm}$. in diameter, on slender pedicels in small lax slightly villose mostly 7-10-flowered cormybs; calyx-tube broad-obconic, villose, with occasional white hairs, the lobes separated by wide sinuses gradually narrowed from the base, short, acute entire or slightly or irregularly toothed, glabrous on the outer surface, villose on the inner surface; stamens 20; anthers dark rose color; styles 3-5. Fruit ripening the end of September, in drooping glabrous clusters, subglobose, dark red, $1 \mathrm{~cm}$. in diameter, the calyx little enlarged with a narrow deep cavity rounded in the bottom, and spreading closely appressed lobes often deciduous from the ripe fruit; nutlets $2-4$, rounded at the ends, rounded and slightly ridged on the back, 6-7 mm. long and $4-5 \mathrm{~mm}$. wide, the narrow pale hypostyle extending for a third of their length. 
A shrub up to $4 \mathrm{~m}$. high, with stems covered with dark bark, thin gray branches armed with many slender straight or slightly curved spines 3-4 $\mathrm{cm}$. long, persistent and becoming compound on old stems, and slender yellow-green glabrous branchlets.

Oнio. H a rding Cou n ty, Mt. Victory, R. E. Horsey, No. 358 (type), May 19 and September 24, 1915.

From the three other species of this group with more or less villose corymbs, twenty stamens and red or rose-colored anthers this new species differs in the shorter often rounded lobes of the much smaller leaves, shorter petioles, smaller and less villose corymbs, and in its globose not short-oblong fruit.

Crataegus Margaretta var. Brownii ( $\S$ Rotundifoliae), n. var.Crataegus Brownii Britton in Bull. N. Y. Bot. Gard. i. 447 (1900).

Differing from the type in its usually narrow-oblong-obovate to elliptic leaves with acute lobes and smaller flowers and fruit.

The leaves of the type of $C$. Margaretta Ashe as it grows in the neighborhood of St. Louis, Missouri, are ovate, rounded at apex, broad-cuneate or rounded at base with short rounded lobes, and about as long as wide; the expanded flowers vary from $1.5-2 \mathrm{~cm}$. in diameter, and the short-oblong fruit is about a centimeter in length. In Missouri, especially in the southern part of the state, trees occur with the typical leaves of the species growing with trees with sharply lobed leaves and smaller flowers and fruit. In northeastern Missouri, trees with broad and with narrow elliptic leaves occur in the neighborhood of Hannibal, and eastward the form with narrower acutely lobed leaves and smaller flowers and fruit is the more abundant. In the region east of the Mississippi River I have seen the typical form only from London, Ontario, from Downer's Grove, Illinois, from Lansing, and Vicksburg, Michigan, from Columbus, Mt. Victory and Delaware, Ohio, from Grant, Allen, Tipton and La Grange Counties, Indiana, and from Sweet Springs and White Sulphur Springs, West Virginia. On the type specimen of Crataegus Brownii from Buchanan, Botetourt County, Virginia, the leaves on the flowering branch vary from elliptic to oblong-obovate, and are not at all or only slightly lobed, and those of a fragment of what appears to be from the end of a young branch are slightly lobed with small rounded lobes. Between the type of $C$. Brownii and that of $C$. Margaretla innumerable forms occur varying in the shape of the leaves and in the size of the flowers and fruit, some of these approaching C. Margaretta and others C. Brownii, and it is impossible in the mass of material before me to find constant characters by which $C$. Brownii can be distinguished from $C$. Margaretta except as a variety. This variety is especially abundant in Allen County, Indiana, where on the east side of Lake Everett about twelve miles northwest of Fort Wayne there is a thicket of these plants some five acres in extent in which Mr. C. C. Deam has found nearly all the forms growing together. 
In the east the most northern station where I have seen the variety growing is at Orbisonia, Huntington County, Pennsylvania.

Crataegus Margaretta f. xanthocarpa, $n$. forma.

Differing from the species only in the bright yellow fruit.

Iowa. Harding County, Steamboat Rock, L. H. Pammel, No. 4 (type)، September 28, 1901, No. 3719, May 24, 1902.

Crataegus Harveyana ( $§$ Intricatae), n. sp.

Leaves ovate, acuminate at apex, cuneate and often unsymmetrical at base, usually divided above the middle into short acute lobes, and finely doubly serrate with straight gland-tipped teeth; early in the season covered above by short white hairs, and pale and villose below along the slender midrib and primary veins, and at maturity dull yellow-green and smooth on the upper surface and paler and nearly glabrous on the lower surface, 4-5 cm. long and 3-4 cm. wide; petioles slender, narrowly wingmargined at apex, often glandular, densely villose early in the season, becoming nearly glabrous, $1-2 \mathrm{~cm}$. in length; leaves at the end of vigorous shoots ovate, acute or acuminate at apex, rounded or cuneate at base, deeply-lobed, coarsely serrate, 6-8 cm. long, and 4-6 cm. wide, their petioles stout with broader margins and more numerous glands. Flowers opening the middle of May, on stout pedicels thickly covered with long white hairs, in many-flowered villose corymbs, with large oblong-obovate sparingly villose glandular bracts and bractlets; calyx-tube broad-obconic, covered with short matted white hairs, the lobes separated by wide sinuses, acuminate, laciniately glandular-serrate above the middle, sparingly villose on the outer surface, glabrous on the inner surface; stamens 20; anthers deep pink; styles 2 or 3 . Fruit ripening the middle of September, subglobose, orange color, $1 \mathrm{~cm}$. in diameter, the calyx little enlarged with a deep narrow cavity pointed in the bottom and spreading often deciduous lobes; flesh thin and dry; nutlets usually 3 , gradually narrowed and rounded at the ends, only slightly ridged on the back, 6-7 $\mathrm{mm}$. long and $5 \mathrm{~mm}$. wide, the narrow dark hypostyle extending nearly to the middle.

A shrub 2-2.5 mm. high, with stems covered with smooth dark bark, and slender nearly straight branchlets thinly covered early in their first season with white matted pale hairs, light red-brown and lustrous in their second season, becoming the following year ashy gray or dark brown, and armed with slender straight chestnut-brown spines $3.5-6 \mathrm{~cm}$. in length.

Arkansas. Carroll County, rocky open woods, Eureka Springs, E. J. Palmer, No. 5532 (16) (type) May 10, 1914, No. 20478 (16) September 10, 1921.

This distinct species is named for Professor Le Roy Harvey who in 1883 published a catalogue of the trees of Arkansas.

Crataegus conjungens ( $§$ Triflorae), n. sp.

Leaves oblong-obovate, acute at apex, gradually narrowed to the concave-cuneate base, and coarsely often doubly serrate with broad acute 
or rounded teeth; nearly half grown when the flowers open and then roughened above by short white hairs and slightly villose below along the midrib, and at maturity dark yellow-green and scabrate on the upper surface and pale and still sparingly villose along the midrib below, $3-4.5 \mathrm{~cm}$. long and 2-2.5 cm. wide; petioles slender, slightly winged at the apex by the decurrent base of the blade, 8-10 mm. in length. Flowers opening the middle of May, 1.5-1.8 cm. in diameter, on slender slightly villose pedicels in small usually 3- or 2- or 1-flowered corymibs, the pedicel of the central flower of the 3-flowered corymb not more than one quarter the length of the others; calyx-tube narrow-obconic, villose, the lobes foliaceous, gradually narrowed from the base, acuminate, laciniately glandular-serrate above the middle, slightly villose; stamens 20; anthers white; styles 3-5. Fruit ripening the end of October, subglobose, orange-red, $1 \mathrm{~cm}$. in diameter, the calyx only slightly enlarged with a short tube, a narrow deep cavity pointed in the bottom and spreading and reflexed lobes; flesh thin and dry; nutlets usually 3 , rounded at the ends, broader at the apex than at the gradually narrowed base, rounded and only slightly grooved or rarely obscurely ridged on the back, 6-7 $\mathrm{mm}$. long and 4-5 $\mathrm{mm}$. wide.

A small shrub with slender branchlets yellow-brown and covered with white matted hairs during their first season and dark gray the following year, and armed with slender straight gray spines $1.5-3 \mathrm{~cm}$. in length.

VIRGINIA. A ll e g ha n y Coun ty, gravelly hill-slopes along the James River, Clifton Forge, T. G. Harbison, Nos. 9 (type) and 16, May 23 and October 25, 1919.

A specimen with young fruit collected by John K. Small on Walker Mountain, at Shannon Gap, Smythe County, Virginia, June 20, 1892, should perhaps be referred to this species. By the shape and size of its leaves, small flowers and fruit and by its general aspect this species might be considered one of the Uniflorae to which plants with 3- or 4-flowered corymbs have been referred. The normally 3-flowered inflorescence, however, with two long and one short central pedicel, the character on which the Triflorae Group is based, is such an important one that I am inclined to refer it to that Group, considering it an intermediate and connecting link between the Uniflorae and Triflorae.

\section{Crataegus choriophylla ( $§$ Uniflorae), n. sp.}

Leaves obovate to elliptic, acute or acuminate at apex, gradually narrowed and cuneate at the glandular base, divided above the middle into short acute lobes, and coarsely often doubly serrate with wide blunt or acute teeth; when they unfold tinged with red and covered above and on the midrib and primary veins below with short white hairs, and at maturity thick dark yellow-green, smooth and lustrous on the upper surface, paler and nearly glabrous on the lower surface, 3-4 cm. long and $2.5-3 \mathrm{~cm}$. wide, with a slender midrib slightly villose toward the base of the leaf and with thin primary veins impressed on its upper surface; petioles stout, narrowly wing-margined at apex, villose early in the season, becoming 
glabrous, glandular, 8-10 mm. in length; leaves at the end of vigorous shoots ovate, long-pointed and acuminate at apex, rounded at the wide base, acutely lobed above the middle, more coarsely serrate, thick and coriaceous, more lustrous on the upper surface, up to $5 \mathrm{~cm}$. long and 4.5 $\mathrm{cm}$. wide, their petioles stout, broad wing-margined nearly to the base, 6 or $7 \mathrm{~mm}$. long. Flowers appearing early in April, about $1.5 \mathrm{~cm}$. in diameter, on slender pedicels covered with long white hairs, in 1- to 5 - usually 3-flowered narrow densely villose corymbs with narrow oblongovate glandular-serrate slightly villose bracts and bractlets; calyx-tube narrow-obconic, villose, the lobes foliaceous, narrow, elongated. acuminate, laciniately glandular-serrate, slightly villose; stamens 20; anthers white; styles 4 or 5 . Fruit ripening in October, on villose pedicels, in 1- or 2-fruited clusters, subglobose to slightly obovoid, orange-red, 1$1.2 \mathrm{~cm}$. in diameter, the calyx little enlarged with a deep narrow cavity pointed in the bottom and spreading and closely appressed lobes; flesh thin and dry; nutlets 4 or 5 , thin and rounded at the ends, rounded and only slightly ridged on the back, $1-1.1 \mathrm{~cm}$. long and $5 \mathrm{~mm}$. wide, the narrow dark hypostyle extending to the middle.

"A small symmetrical tree with erect or spreading branches, bark ashy gray and shallowly furrowed" with stout nearly straight unarmed branchlets light yellow-green and conspicuously covered early in their first season with matted pale hairs, becoming nearly glabrous and dull red-brown at the end of their first season and dark gray-brown the following year.

Florida. C o l u m bi a C o u n ty, Lake City, in dry sandy soil, T. G. Harbison No. 12, June 23, 1917, Nos. 5687 (type) and 5687a, April 11 and October 8, 1920.

This plant is doubtfully referred to the Uniflorae. From the other species of that Group it differs in the broad-ovate coriaceous leaves on vigorous shoots, the more numerous-flowered corymbs, spineless branches and in its arborescent habit. Mr. Harbison who discovered it thought at one time that it might belong to the Flavae Group. "This," he writes, " is one of the most distinct looking of the genus. When I first saw it I was inclined to think that it might be a hybrid. In general appearance it does not suggest the Flavae Group. The sepals look like those of some of the Uniflorae, and the fruit is firm like the fruit of most of the species of that group."

\section{Crataegus Croomiana (§ Uniflorae), n. sp.}

Leaves obovate to rhombic, acute at apex, gradually narrowed and cuneate at base, coarsely serrate above the middle with rounded or acute teeth; roughened above early in the season by short white hairs, and sparingly villose below especially on the slender midrib and obscure primary veins, and at maturity thin, blue-green and slightly roughened above, paler and nearly glabrous below, $2.5-3 \mathrm{~cm}$. long and $1.5-2 \mathrm{~cm}$. wide; petioles slender, slightly winged at apex by the decurrent blade, densely 
villose early in the season, becoming nearly glabrous, $3-6 \mathrm{~mm}$. in length; leaves at the end of vigorous shoots broad-obovate to suborbicular, occasionally slightly lobed with short rounded lobes, more coarsely serrate, up to $3 \mathrm{~cm}$. in diameter. Flowers opening the middle of April, $1 \mathrm{~cm}$. in diameter, nearly sessile, solitary (on the single specimen in this herbarium), the short pedicels thickly covered with long matted white hairs; calyx broad-obconic, villose, the lobes slender, acuminate, nearly entire or laciniately glandular-serrate above the middle, villose; stamens 20 ; anthers rose color; styles 5 . Fruit obovoid, gradually tapering to the base, 1-1.2 cm. long, 8-9 mm. in diameter, the calyx prominent with a short tube, a broad deep cavity pointed in the bottom, and spreading and reflexed much enlarged lobes; flesh thin, dry and mealy; nutlets 5, rounded at apex, gradually narrowed and acute at base, rounded and grooved on the back, 6-7 $\mathrm{mm}$. long and $3 \mathrm{~mm}$. wide, the narrow dark hypostyle extending nearly to the base.

A shrub $1.5-2 \mathrm{~mm}$. high, with very slender branchlets covered early in the season with matted pale hairs, dull red-brown and slightly pubescent, becoming glabrous in their second season, and ashy gray and glabrous the following year, and armed with numerous slender dark chestnut brown spines $2-4 \mathrm{~cm}$. in length.

Florida. L e o n County, upland woods in sandy soil near, Tallahassee, T. G. Harbison Nos. 5710 (type) and 5710a, April 15 and October 6, 1920.

This species generally resembles $C$. uniflora Moench, the type of the Group, which differs from the Tallahassee plant by its usually more pubescent leaves, yellow anthers, subglobose rarely slightly obconic fruit with a more enlarged calyx. It is named for Henry B. Croom, a native of Newbern, North Carolina, who for many years visited his plantations in western Florida every winter, and in 1833 discovered Torreya on the bank of the Appalachicola River, and who wrote and published papers on the flora of the southern states.

Crataegus Victorinii (§ Macracanthae), n. sp.

Leaves ovate to oval or obovate, rounded and short-pointed or acute at apex, abruptly concave-cuneate at base, often slightly and irregularly lobed with acuminate lobes, and sharply doubly serrate usually only above the middle with straight teeth; nearly fully grown when the flowers open and then glabrous with the exception of a few hairs on the upper side of the midrib, and at maturity thin, glabrous, dull dark green on the upper surface, paler on the lower surface, $3.5-4 \mathrm{~cm}$. long and 2.5-3 $\mathrm{cm}$. wide, with a stout midrib and prominent veins impressed above; petioles stout, narrow, wing-margined to the middle, glabrous, $1-1.5 \mathrm{~cm}$. in length; leaves on vigorous shoots obovate, rounded at apex, more acutely cuneate at base, lobed with longer acuminate lobes, $4.5-5 \mathrm{~cm}$. long and 3-4 $\mathrm{cm}$. wide. Flowers opening early in June, $1.5 \mathrm{~cm}$. in diameter, on long slender pedicels in wide 10-25-flowered glabrous corymbs; calyx-tube 
broad-obconic, glabrous, the lobes separated by wide sinuses, laciniately glandular-serrate, glabrous on the outer surface, puberulous on the inner surface; stamens 10; anthers rose color; styles 2-5. Fruit ripening the middle of September, on slender drooping pedicels in many-flowered clusters, subglobose, scarlet, lustrous, $8-10 \mathrm{~mm}$. in diameter, the calyx little enlarged with a short tube, spreading and reflexed lobes, and a deep narrow cavity pointed in the bottom; flesh thick and succulent; nutlets 2-5, rounded at apex, narrowed at base, only slightly grooved on the back, penetrated on the inner face by narrow shallow grooves, the narrow dark hypostyle extending to about the middle.

A round-topped tree 4-5 m. high, with yellow-green bark and stout glabrous branchlets very rarely furnished with stout nearly straight chestnut-brown spines $5 \mathrm{~cm}$. long or entirely spineless, yellow-green when they first appear, becoming chestnut-brown, lustrous and marked by pale lenticels at the end of their first season and dark red-brown the following year.

Canada. Province of Quebec, Longueuil, opposite Montreal, in the grounds of College Longueuil Brother Victorin, No. 27 (type), June 4 and September 22, 1913; Outremont, Montreal Island, Brother Victorin, No. 31, May 29 and September 11, 1914.

Glabrous species in the Macracanthae are rare. On page 10 of this volume of the Journal one of these, C. nuda Sarg. of southern Missouri, was described and of the eastern species previously described only one, $C$. bristoliensis Sargent from southern Massachusetts, has ten stamens and rose-colored anthers. The other species have yellow anthers. From $C$. bristoliensis this new species differs in its larger, thinner and more deeply and regularly lobed acuminate leaves, in its narrow calyx-lobes, in its ellipsoidal to obovoid fruit, and in its more numerous spines.

Crataegus carrollensis ( $\$$ Macracanthae), n. sp.

Leaves ovate to rarely obovate, acuminate at apex, abruptly or gradually narrowed and concave-cuneate at base, slightly and irregularly divided usually only above the middle and coarsely often deeply serrate with straight gland-tipped teeth; more than half grown when the flowers open and then covered above with short white hairs and slightly villose below especially on the midrib and veins, and at maturity thin, yellowgreen, smooth, lustrous and glabrous above, still villose below, $7-10 \mathrm{~cm}$. long and 5.5-7 $\mathrm{cm}$. wide, with a stout midrib and slender primary veins; petioles stout, wing-margined toward the apex by the decurrent leaf blade, densely villose early in the season, becoming pubescent in the autumn 2-2.5 cm. in length. Flowers (only buds seen) in many-flowered corymbs, densely covered with matted white hairs, with conspicuous oblong-obovate to linear-lanceolate bracts and bractlets; calyx-tube narrow-obconic, villose, the lobes narrow-acuminate, laciniately glandular-serrate, sparingly villose or glabrous on the outer surface, glabrous on the inner surface; stamens 15-20; anthers pale yellow; styles 2 or 3 . Fruit ripening pro- 
bably in October, on stout glabrous pedicels, ellipsoidal, dark red, the calyx with a short tube, spreading and reflexed lobes and a shallow wide cavity pointed in the bottom, 6 or $7 \mathrm{~mm}$. long and 5 or $6 \mathrm{~mm}$. wide; nutlets 2 or 3 , acute at apex, rounded at base, slightly grooved on the back, penetrated on the inner face by short grooves, $5 \mathrm{~mm}$. long and $3 \mathrm{~mm}$. wide, with a narrow hypostyle extending to the middle.

A stout shrub 2-3 m. high, covered with gray scaly bark, thick erect pale gray branches and stout branchlets yellow-green and sparingly covered with pale hairs when they first appear, becoming red-brown and glabrous in their second season and armed with numerous stout straight chestnut brown lustrous spines 4-6.5 cm. long, becoming branched and persistent on old stems.

Arkansas. C a r r o $11 \mathrm{C}$ o u n t y, rocky hillsides, Eureka Springs, E. J. Palmer, No. 5521 (type), September 23, 1913, No. 5521, May 9, 1914.

\section{Crataegus kingstonensis ( $§$ Anomalae), n. sp.}

Leaves elliptic to broad-ovate, acuminate at apex, gradually narrowed and cuneate or rarely rounded at base, divided toward the apex into short acuminate spreading lobes, and coarsely often doubly serrate above the middle with straight glandular teeth, thin, glabrous, dark yellow-green, smooth and lustrous above, pale or glabrous below, 5-7 cm. long and 4-5 $\mathrm{cm}$. wide, with a slender midrib and primary veins; petioles slender, 1-1.5 $\mathrm{cm}$. in length. Flowers opening early in June on long slender pedicels in lax mostly 7-10-flowered glabrous corymbs; calyx-tube broad-obconic, glabrous, the lobes gradually narrowed from the base, acuminate, sharply serrate or entire, glabrous on the outer surface, puberulous on the inner surface; stamens 20; anthers bright red; styles 4 or 5 . Fruit ripening the middle of October, subglobose, about $1.5 \mathrm{~cm}$. in diameter, dark red, with soft succulent flesh; the calyx little enlarged with spreading appressed lobes and a deep narrow cavity rounded in the bottom; nutlets 4 or 5 , rounded at the ends, ridged on the back with a low grooved ridge, obscurely grooved on the inner faces, 6-7 mm. long and 5-6 $\mathrm{mm}$. wide, the narrow hypostyle extending to the middle.

A tree 7-8 m. high, with a trunk $2 \mathrm{~m}$. long, and stout glabrous branchlets yellow-green when they first appear, becoming dark chestnut brown and lustrous by the end of the first season and dull red-brown the following year, and armed with many stout nearly straight chestnut-brown spines $3-4 \mathrm{~cm}$. in length.

Canada. Provin ce of O $\mathrm{n}$ t a r i o, near Kingston, J. Dunbar, No. 113 (type) and No. 117, October 19, 1911, June 6, 1912.

This is an interesting addition to the small number of Anomalae with glabrous corymbs and 20 stamens. It is most closely related to $C$. fallsiana Sarg. from Little Falls, Herkimer County, New York, with the same shaped leaves and the same succulent fruit, but the flowers and fruit of the Kingston tree are much larger. The two species are more 
distinct in the roughness of the upper surface of the leaves of the New York plant at the time the flowers open, caused by the bases of the hairs which cover it as the leaves unfold, those of $C$. kingstonensis being always glabrous.

Betula neoalaskana, n. nom.-Betula alascana Sargent in Bot. Gaz. xxxi. 236 (1901), not Lesquereux in Proc. U. S. Nat. Mus. v. 446 (1883).

Dr. C. V. Piper calls my attention to this earlier use of the name Betula alaskana for a fossil tree necessitating a new name for the existing species.

\section{Gleditsia texana Sargent.}

This species was based on a grove of trees growing near Brazoria in the valley of the lower Brazos River in Tezas. When these trees were described in 1901 only the Brazoria trees were known but since 1901 specimens of what is evidently the same tree have been collected on the banks of the Red River near Shreveport, Louisiana, at Yazoo City, Mississippi, and by a roadside $1 / 2$ mile west of Skelton, Gibson County, Indiana (C. C. Deam No. 35,123, September 27, 1921). On the Brazos River $G$. texana grows in company with $G$. triacanthos Linnaeus and G. aquatica Marshall and these species occur in the other localities where this tree has been met with; and as only a few individuals have been found in widely scattered localities there seems every reason to believe that $G$. texana is a hybrid of $G$. triacanthos and $G$. aquatica.

The trees have the habit of G. triacanthos and the branches of the Texas tree are unarmed but those from Louisiana are furnished with stout simple spines and on the Indiana tree the spines are stout or compound. The leaves of these trees resemble those of $G$. triacanthos, but they all have short thin walled fruit without the pulp of that species and in this resemble $G$. aquatica. On one of the Louisiana specimens the fruit varies in length from 6-11 $\mathrm{cm}$. The longest of these fruits have the straight margins and the rounded base of that of $G$. triacanthos, on some of the shortened fruits the margins are more or less contracted between the seeds and the shortest are one-seeded and generally narrowed into a long cuneate base. The length of the fruits of the Mississippi specimen collected by S. M. Tracy are $10 \mathrm{~cm}$. long with a rounded base, deeply contrated between the three seeds and the shorter is $4 \mathrm{~cm}$. long with a stipelike base and one seed.

Thomas Nuttall landed in January 1819, on an island in the Mississippi River near the mouth of White River, Arkansas "and for the first time recognized the short podded, honey-locust (Gleditsia brachycarpa), a distinct species, intermediate with the common kind (G. triacanthos) and the one-seeded locust (G. monosperma), differing from $G$. triacanthos in the persisting fasciculated legumes, as well as in their shortness and want 
of pulp." (Travels into the Arkansas Territory p. 63). A few days later he saw the three Gleditsias growing together on the banks of the lower Arkansas River. Judging by the locality Nuttall's G. brachycarpa is the hybrid of G. texana and not the G. brachycarpa of Pursh which was from the mountains of Southwestern Virginia a region far beyond the range of G. aquatica. As a synonym of his species Pursh quotes G. triacanthos brachycarpos of Michaux for which Michaux gave no locality.

\section{NEW SPECIES, VARIETIES AND COMBINATIONS FROM THE HERBARIUM AND THE COLLECTIONS OF THE ARNOLD ARBORETUM ${ }^{1}$}

\section{Alfred Rehder}

Juniperus squamata var. Meyeri, var. nov.

A typo recedit habitu erecto vel ascendente foliis dorso eximie glaucis. Frutex humilis, ramis erectis vel ascendentibus dense ramulosis ramulis brevibus erectis vel suberectis; internodia brevia pallide luteo-viridia; folia lineari-lanceolata, 6-10 mm. longa, circiter $1.5 \mathrm{~mm}$. lata, a medio in apicem spinulosam sensim attenuata, dorso fere ad apicem leviter sulcata, ventre fasciis duobus albis stomatiferis notata, nervo medio leviter elevato glauco; fructus plerique ad basin ramulorum, erecti, pedunculo brevissimo dense bracteato suffulti, ovoideo-oblongi, circiter $6 \mathrm{~mm}$. longi (ut videtur non bene evoluti et steriles) medio squamulorum apicibus liberis triangularibus plerumque 3 instructi, apice depressi, atro-brunnei, demum fere atri, levissime pruinosi; semen conico-ovoideum acutum et apiculatum, 2-3- costatum.

Cultivated at the Arnold Arboretum (plants received from Hick's Nursery as "Meyer's Juniper;" specimens collected October 3, 1919, September 15, 1922 (type); U. S. Department of Agriculture, S. P. I. No. 23023, comm. H. C. Skeels, November, 1921 .

This Juniper was found by Frank N. Meyer in Tientsin, Chili, grown by the Chinese as a pot plant and supposed to have come from southwestern Shantung. The Chinese graft it on Thuja orientalis; how this is done is shown by Meyer's photograph No. 12258 taken near Shin yeh, Honan; an older plant of this variety is shown in his photograph No. 12407, taken at Peking. This Juniper is a very handsome form on account of its striking blue-white color and its dense habit. From the commonly cultivated form of $J$. squamaia Lambert it is chiefly distinguished by the dense upright or ascending habit and by the bluish white longer leaves. It has proved perfectly hardy at the Arnold Arboretum and fruited this year for the first time, though the seeds were sterile.

${ }^{1}$ Continued from p. 51. 


\section{$2 \mathrm{BHL}$ Biodiversity Heritage Library}

Sargent, Charles Sprague. 1922. "Notes on North American Trees, X." Journal of the Arnold Arboretum 3(4), 182-207. https://doi.org/10.5962/p.185178.

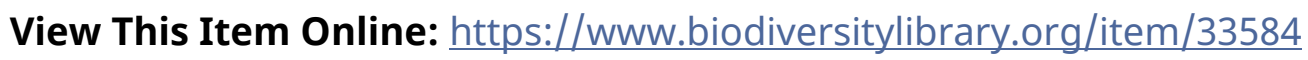

DOI: https://doi.org/10.5962/p.185178

Permalink: https://www.biodiversitylibrary.org/partpdf/185178

\section{Holding Institution}

Missouri Botanical Garden, Peter H. Raven Library

\section{Sponsored by}

Missouri Botanical Garden

\section{Copyright \& Reuse}

Copyright Status: Public domain. The BHL considers that this work is no longer under copyright protection.

This document was created from content at the Biodiversity Heritage Library, the world's largest open access digital library for biodiversity literature and archives. Visit BHL at https://www.biodiversitylibrary.org. 